\title{
The effect of human proinsulin C-peptide on erythrocyte deformability in patients with Type I diabetes mellitus
}

\author{
T. Kunt ${ }^{*}$, S. Schneider ${ }^{1 *}$, A. Pfützner ${ }^{1}$, K. Goitum ${ }^{1}$, M. Engelbach ${ }^{1}$, B. Schauf ${ }^{2}$, J. Beyer ${ }^{1}$, T. Forst ${ }^{1}$ \\ ${ }^{1}$ Department of Endocrinology, University of Mainz, Germany \\ ${ }^{2}$ Department of Obstetrics and Gynaecology, University of Giessen, Germany
}

\section{Abstract}

Aims/hypothesis. In recent years, evidence has arisen that proinsulin C-peptide exerts biological effects especially on microcirculation, e.g. C-peptide has been shown to increase skin microcirculation in patients with Type I (insulin-dependent) diabetes mellitus and to activate endothelial nitric oxide synthase. This study aimed to investigate the influence of proinsulin C-peptide on erythrocyte deformability which was assessed by means of laser diffractoscopy.

Methods. Blood samples from healthy control subjects $(n=10)$ and Type I diabetic patients $(n=15)$ completely deficient of C-peptide were analysed at shear stresses ranging from 0.3 to $30 \mathrm{~Pa}$.

Results. Erythrocyte deformability was lower in the group of Type I diabetic patients than in the control subjects. Preincubation of the diabetic blood samples with various concentrations of human proinsulin Cpeptide for $8 \mathrm{~h}$ restored the deformability of erythrocytes, almost reaching the values of control samples. In contrast, proinsulin C-peptide did not modify the erythrocyte deformability of control subjects.

Conclusion/interpretation. We conclude that proinsulin C-peptide is able to ameliorate the impaired deformability of erythrocytes in Type I diabetic patients and we hypothesise that this effect is mediated by restoration of $\mathrm{Na}^{+}-\mathrm{K}^{+}$-ATPase activity, which is known to be attenuated in diabetic patients. [Diabetologia (1999) 42: 465-471]

Keywords Proinsulin C-peptide, erythrocyte deformability, microcirculation, laser diffractoscopy, shear stress.
Human proinsulin C-peptide is a cleavage product of insulin secretion in the beta cells of the islets of Langerhans. It is released in amounts equal to insulin into the portal circulation [1]. It has been held that its main function is to enable the folding of the proinsulin molecule by facilitating the formation of the disulphide bonds of the A- and B-chain [2] Since its discovery [3], a few studies have investigated a potential biological role of proinsulin C-peptide but with nega-

Received: 27 August 1998 and in final revised form: 15 December 1998

* T. Kunt and S. Schneider contributed equally Corresponding author: T. Kunt, M.D., Department of Endocrinology, University Hospitals, Langenbeckstrasse 1, 55131 Mainz, Germany

Abbreviations: $\mathrm{R}_{\mathrm{i}}$, inner cylinder radius; $\mathrm{A} / \mathrm{D}$, analogue/digital. tive results $[4,5]$. In recent years, however, evidence was raised that human proinsulin C-peptide exerts several physiological effects [6]. It has been shown to influence insulin secretion by a feedback mechanism [7] and to ameliorate glucose metabolism and oxygen uptake in skeletal muscle $[8,9]$. In addition, C-peptide is able to elicit beneficial effects on renal and neural functions in patients with Type I (insulin-dependent) diabetes mellitus [10-12]. Recently, we showed that C-peptide increases the nutritional blood flow in the skin of Type I diabetic patients [13]. In a subsequent in vitro study, we found the potential underlying mechanism could be that C-peptide activates endothelial nitric oxide synthase in a calcium dependent way [14]. These findings encouraged us to extend our studies concerning the microvascular effects in the field of haemorrheology. It is well known that the properties of diabetic erythro- 
cytes are abnormal [15-18]. These abnormalities include decreased deformability [19, 20], increased membrane microviscosity [21] and increased erythrocyte aggregation [22]. The molecular basis for these abnormalities is not known but it seems likely that non-enzymatic glycosylation of proteins with subsequent antioxidative imbalance is mainly involved in erythrocyte dysfunction $[23,24]$. In addition, modifications of lipid composition of the erythrocyte membrane and disturbances in ion homeostasis related to decreased $\mathrm{Na}^{+}-\mathrm{K}^{+}$-ATPase activity have been shown to occur under diabetic conditions, the latter leading to an intracellular accumulation of sodium and calcium ions $[16,25,26]$.

This study aimed to investigate the influence of human proinsulin C-peptide on the deformability of erythrocytes in C-peptide-deficient (Type I) diabetic patients. The study used a PC-based laser diffractoscopy technique, which has been established as a valid system with high accuracy, to analyse erythrocyte deformability as an important factor of microcirculation [27-29].

\section{Materials and methods}

Materials and blood samples. Ammonium-heparinated blood samples were collected from 10 healthy control subjects and 15 Type I diabetic patients (Table 1). All of them were nonsmokers, had no history of hypertensive disease or any other vascular disease and were not under any medication other than insulin.

All experiments were carried out at a room temperature of $20 \pm 1^{\circ} \mathrm{C}$ which was thermostatically regulated. All samples and solutions used in the experiments were also prepared and stored at $20^{\circ} \mathrm{C}$.

The high-viscosity solution consisted of $20 \mathrm{ml}$ erythrocyte washing solution and $5 \mathrm{~g}$ Dextran 60.000 (Shiwa, Glandorf, Germany). The washing solution consisted of $140 \mathrm{mmol} \mathrm{NaCl}$, $4 \mathrm{mmol} \mathrm{KCL}, 6 \mathrm{mmol}$ glucose and $0.5 \mathrm{mmol}$ TRIS buffer dissolved in one litre distilled water ( $\mathrm{pH} 7.40)$. Viscosity was tested with a viscosimeter and fixed to 22.5 cpoise. The solution was isotonic. No deformation or deviation of erythrocytes after 30 min of incubation could be detected by microscope or, concerning flexibility, by using the laser diffractoscope.

Laser diffractoscopy (Fig. 1). The laser diffractoscope (purchased from the Department of Laser Medicine, HeinrichHeine University, Düsseldorf, Germany) is another method for measuring erythrocyte deformation. It consists of a HeNe-laser $(25 \mathrm{~mW} ; 632.8 \mathrm{~nm})$, a measuring chamber and personal computer-based image analysis system. The laser beam is coupled via a dove prism into the rotational axis of the measuring chamber. The measuring chamber consists of a viscosimeter which is used to produce well-defined shear stress within a gap of $0.5 \mathrm{~mm}$ between two transparent cylinders. The rotating inner cylinder $\left(\mathrm{R}_{\mathrm{i}}=24.5 \mathrm{~mm}\right)$ offers the advantage of effortless gap filling and emptying and, most importantly, the absence of lens effects of the outer $\left(R_{i}=25 \mathrm{~mm}\right)$ non-rotating cylinder (Searle flow system) due to its plane front face. The gap between the inner and the outer cylinder was filled with the sample $(250 \mu \mathrm{l}$ of whole heparinised blood) suspended in $4 \mathrm{ml}$ of high viscosity dextran. The rotational speed was constantly be-
Table 1. Characteristics of included subjects

\begin{tabular}{llll}
\hline & $\begin{array}{l}\text { healthy control } \\
\text { subjects }\end{array}$ & $\begin{array}{l}\text { diabetic } \\
\text { patients }\end{array}$ & $p$ value \\
\hline age (years) & $29.9 \pm 4.4$ & $28.8 \pm 6.5$ & NS \\
blood glucose $(\mathrm{mmol} / \mathrm{l})$ & $4.52 \pm 0.42$ & $6.55 \pm 1.19$ & $<0.001$ \\
HbA $_{1 \mathrm{c}}$ & $5.0 \pm 0.2$ & $6.8 \pm 0.7$ & $<0.0001$ \\
C-peptide $(\mathrm{nmol} / \mathrm{l})$ & $0.33 \pm 0.10$ & $<0.03$ & - \\
\hline
\end{tabular}

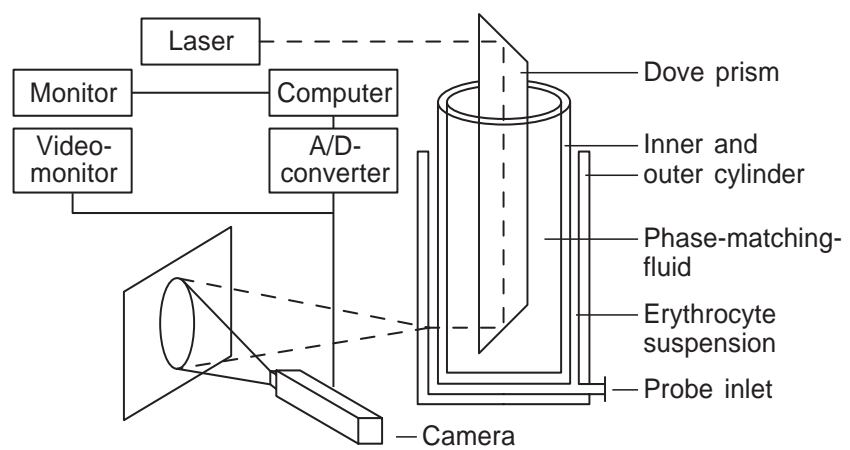

Fig. 1. Scheme of the laser diffractoscope (refer to Materials and methods)

ing checked by a light barrier-coupled feedback mechanism and computer-assisted control. Moreover, a position control device was used to grab images at selected positions of the cylinder. Thus, the variation coefficient of the measurement of erythrocyte deformability could be reduced to less than $0.5 \%$.

The shear rate produced in the gap can, therefore, be expressed by the following linear approximation:

shear rate $\left(\mathrm{s}^{-1}\right)=\left(2 \pi * \mathrm{R}_{\mathrm{i}} * \mathrm{rpm}\right) /(60 * \mathrm{~h})$

where $\mathrm{R}_{\mathrm{i}}=$ inner cylinder radius, $\mathrm{rpm}=$ rotation rate (rounds per minute), and $\mathrm{h}=$ gap thickness $(0.5 \mathrm{~mm})$. The shear stress (Of) in turn is given by:

$\mathrm{f}(\mathrm{Pa})=$ shear rate $* \eta * 1 / 10$

The rate of rotation ranges from 0 to $250 \mathrm{rpm}$, giving a shear rate range from 0 to $1370 \mathrm{~s}^{-1}$ and a shear stress range from 0 to $30 \mathrm{~Pa}$.

During the passage of the laser beam, the laser light is diffracted forming an image correlating to the shape of all erythrocytes that pass the laser beam. Thus, the diffraction image represents the mean deformability of all these erythrocytes. In this experiment, approximately 22.5 million erythrocytes contributed to this single diffraction image. This image was detected by a CCD-camera, being analogue/digital (A/D)converted and fed into an IBM compatible personal computer. All areas of the same intensity in the diffraction image contribute to an isointensity line (Fig. 2) which is correlated to an ellipse. Up to 30 isointensity lines were evaluated by this method, each of them showing a different elongation value $\mathrm{E}$, which was defined as: $\mathrm{E}=$ diameter (major axis) - diameter (minor axis)/diameter (major axis) + diameter (minor axis). From these elongation values, a mean E-value was evaluated showing a standard deviation of less than $1 \%$. The complete procedure of the measurement of one sample at one shear rate took less than $1 \mathrm{~min}$; additional measurements at different shear rates took 10 to $30 \mathrm{~s}$ per measurement depending on the shear rate. The evaluation of the deformability by com- 


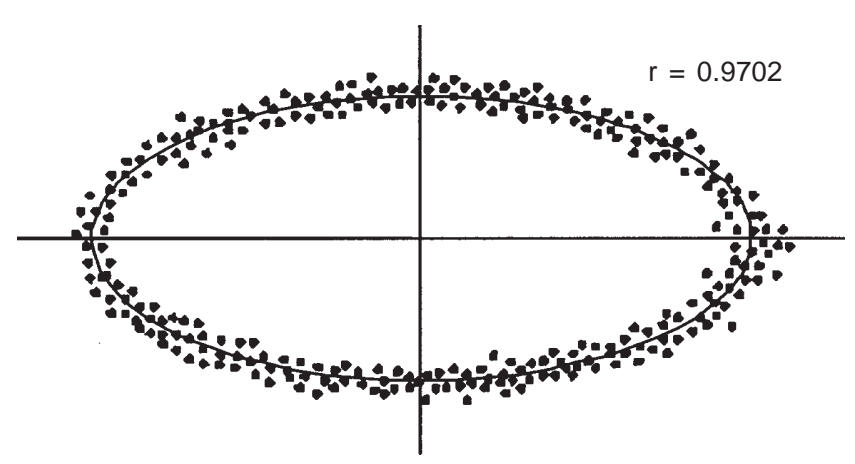

Fig. 2. Analysis of the generated diffraction image. About 22.5 million erythrocytes contributed to the diffraction image which was detected by a videocamera, analogue/digital-converted and analysed by a personal computer. Image analysis identified areas of identical intensity, thus forming isointensity lines. A representative analysis of one intensity done at a shear stress of $1.75 \mathrm{~Pa}$ is shown. An elliptical shape of these lines is regarded as given if the correlation coefficient is higher than 0.95

puter-assisted analysis was carried out off-line. The samples from patients and control subjects were incubated with various concentrations of human proinsulin C-peptide $(0,0.6,6.6$ and $66.6 \mathrm{nmol} / \mathrm{l}$; kind, gift of R. Chance, Eli Lilly, Indianapolis, USA) diluted in phosphate buffered saline with $0.2 \%$ bovine serum albumin. Incubation periods were 0,4 and $8 \mathrm{~h}$ prior to measurements.

In subsequent experiments, erythrocytes were incubated with $1 \mu \mathrm{mol} / \mathrm{l}$ ouabain $30 \mathrm{~min}$ prior to $\mathrm{C}$-peptide treatment to inhibit $\mathrm{Na}^{+}-\mathrm{K}^{+}$-ATPase. Treatment with ouabain alone did not alter erythrocyte deformability.

Statistical analysis. The results are expressed as the means \pm SD. Gaussian distribution was checked by the KolmogoroffSmirnoff test. Statistical analyses were done by two-site ANOVA and Student's $t$ test. A $p$-value of less than 0.05 was regarded as statistically significant.

\section{Results}

Firstly, to show that erythrocyte deformability is not being modified during the test period, blood samples of healthy control subjects were measured over $8 \mathrm{~h}$. The elongation index $\mathrm{E}$ remained unchanged showing a high reproducibility due to low intra- and interassay variability.

To characterise the deformability of diabetic erythrocytes, samples from healthy control subjects $(n=10)$ and Type I diabetic patients $(n=15)$ were investigated (Table 1$)$. The concentrations of blood glucose and glycated haemoglobin were noticeably different in both groups. Furthermore, only patients who were absolutely proinsulin C-peptide deficient were included in the study.

According to studies using microscopical or filtration techniques, the deformability of diabetic erythrocytes is decreased compared with healthy control subjects (Fig.3). This difference was detectable in a

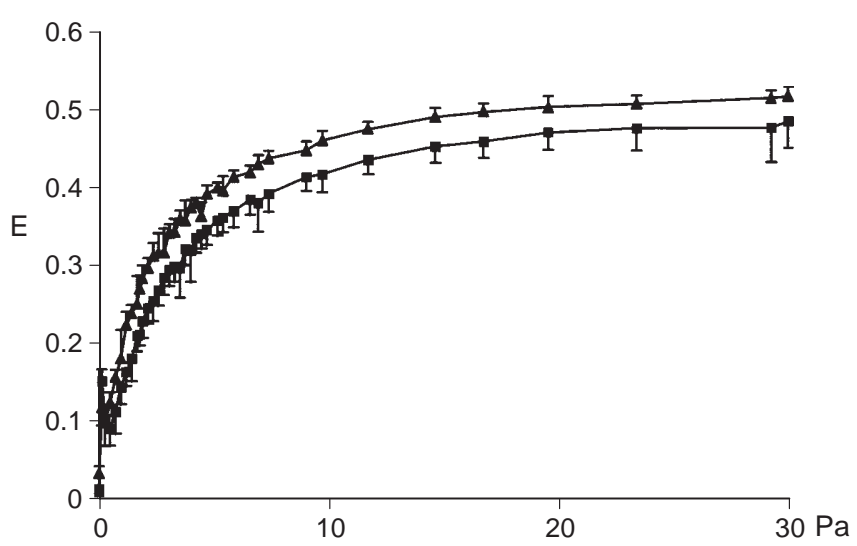

Fig. 3. Measurement of elongation index $\mathrm{E}$ in diabetic patients and control subjects. Compared with healthy control subjects $(\boldsymbol{A})$, the elongation index $\mathrm{E}$ of the erythrocytes was considerably lower $(p<0.0001)$ in Type I diabetic patients $(\square)$ at all tested shear rates. Statistical analysis was performed by twosite ANOVA

wide range from low to supraphysiological ( $>10 \mathrm{~Pa}$ ) shear stress in this experiment.

After incubation with C-peptide for $4 \mathrm{~h}$, erythrocyte deformability increased in the diabetic group considerably to levels almost similar to and statistically not different from the control group (Fig.4). This effect was seen in all C-peptide concentrations ( 0.6 to $66.6 \mathrm{nmol} / \mathrm{l})$. Furthermore, the effect of proinsulin C-peptide was constant over the period of $8 \mathrm{~h}$ (data not shown). In contrast, C-peptide did not modify the erythrocyte deformability of healthy control subjects at either concentration (Fig. 5).

At a frequently achieved physiological shear stress rate of $1.75 \mathrm{~Pa}$ (Fig. 6), C-peptide (6.6 nmol/l) restored the erythrocyte deformability from an $\mathrm{E}$ value of $0.2081 \pm 0.013$ to $0.2669 \pm 0.021(\mathrm{p}=0.002)$, which was not different from that of the control group $(E=0.2630 \pm 0.014$; NS $)$. These effects of C-peptide are constant over the whole shear range, e.g. at 7.11 $\mathrm{Pa}$, the $\mathrm{E}$ value of diabetic erythrocytes with and without C-peptide $(6.6 \mathrm{nmol} / \mathrm{l})$ was $0.4215 \pm 0.010$ and $0.3794 \pm 0.023(p=0.002)$, respectively and thus after C-peptide treatment not different from erythrocytes of healthy control subjects $(E=0.4306 \pm 0.006$; NS).

To investigate the role of $\mathrm{Na}^{+}-\mathrm{K}^{+}$-ATPase activity in the restoration of erythrocyte deformability by $\mathrm{C}$ peptide, laser diffractoscopic measurements were taken with and without pretreatment of the cells with $1 \mu \mathrm{mol} / \mathrm{l}$ ouabain. Again, erythrocyte deformability was restored by C-peptide over the whole shear range $(p<0.0001$ vs control cells as analysed by two-site ANOVA), but this effect was totally abolished by pretreatment with ouabain (Fig. 7) 

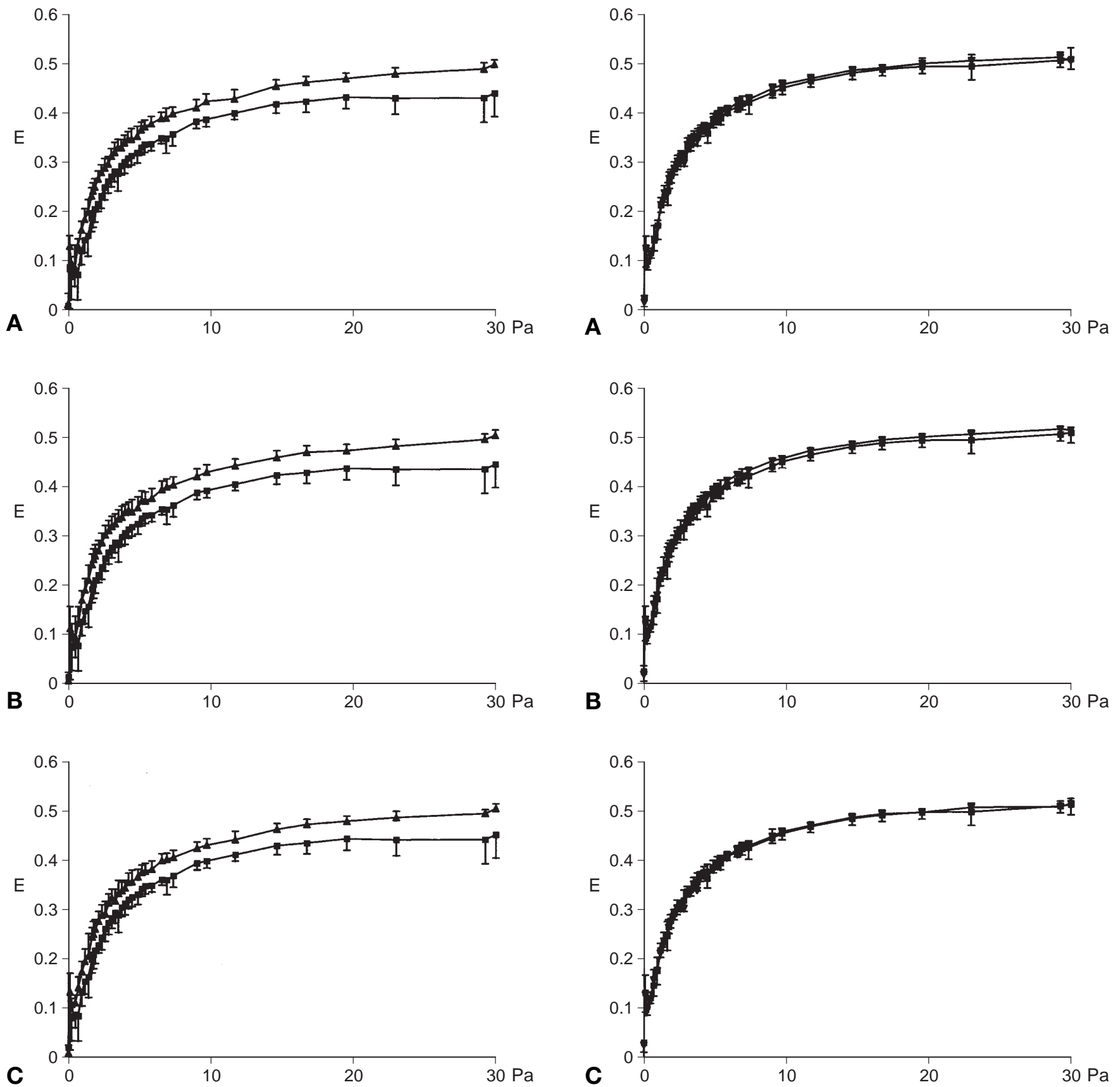

Fig. 4. A-C Influence of C-peptide on erythrocyte deformability in diabetic patients. Proinsulin C-peptide $(\boldsymbol{\Delta})$ given at concentrations of $0.6 \mathrm{nmol} / \mathrm{l}(\mathbf{A}), 6.6 \mathrm{nmol} / \mathrm{l}(\mathbf{B})$ and $66.6 \mathrm{nmol} / \mathrm{l}$ (C) restored the deformability (expressed by the elongation index E) of diabetic erythrocytes ( $)$ to levels which were statistically not different $(p<0.0001$ for all concentrations, as tested by two-site ANOVA) from erythrocytes of healthy control subjects. The erythrocytes of the diabetic control subjects were treated only with phosphate buffer

\section{Discussion}

Diabetes mellitus is associated with morphological and functional alterations in microcirculation. The aetiology of microvascular dysfunction is not fully understood but several mechanisms have been dis-

Fig. 5. A-C Influence of C-peptide on erythrocyte deformability in healthy control subjects. Neither of the C-peptide concentrations $(\boldsymbol{\nabla})$ used influenced the elongation index $E$ of the erythrocytes of healthy control subjects $(\square)$ at physiological and supra-physiological shear rates ranging from 0.3 to $30 \mathrm{~Pa}$. (A) $0.6 \mathrm{nmol} / 1 \mathrm{C}$-peptide; (B) $6.6 \mathrm{nmol} / 1 \mathrm{C}$-peptide; (C) 66.6 nmol/l C-peptide)

cussed [30]. Besides increased capillary shunt flow (due to peripheral diabetic neuropathy of the $\mathrm{C}$ fibres [31], attenuated axon reflex response [32] and increased leucocyte-endothelial interaction due to stimulated leucocyte integrins and endothelial adhesion molecules $[33,34]$ ), alteration of blood viscosity [20] is an important component of the hypothesis 


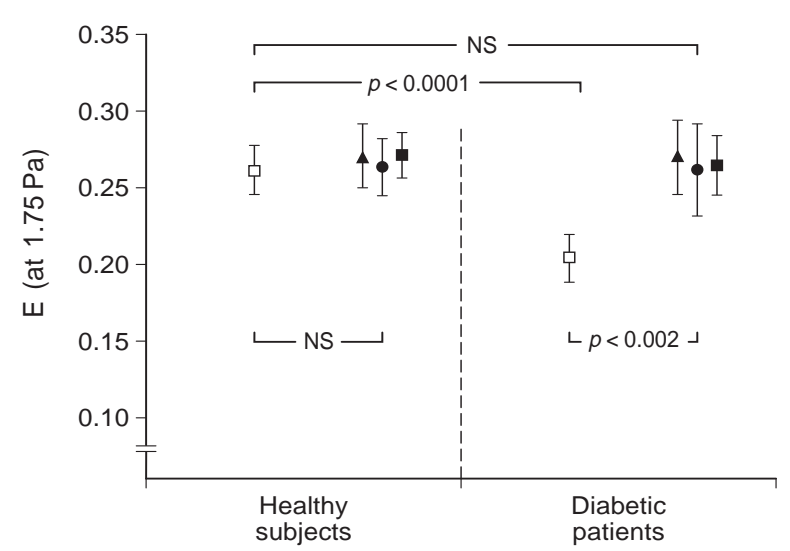

Fig. 6. Representative analysis of erythrocyte deformability at $1.75 \mathrm{~Pa}$. This graph shows the alterations of elongation index $\mathrm{E}$ at a shear stress of $1.75 \mathrm{~Pa}$, which is frequently achieved in vivo. C-peptide did not modify the deformability of erythrocytes obtained from healthy control subjects, whereas the deformability of diabetic erythrocytes was restored to normal levels after treatment with different concentrations of the peptide. Statistical analysis was performed by Student's $t$ test

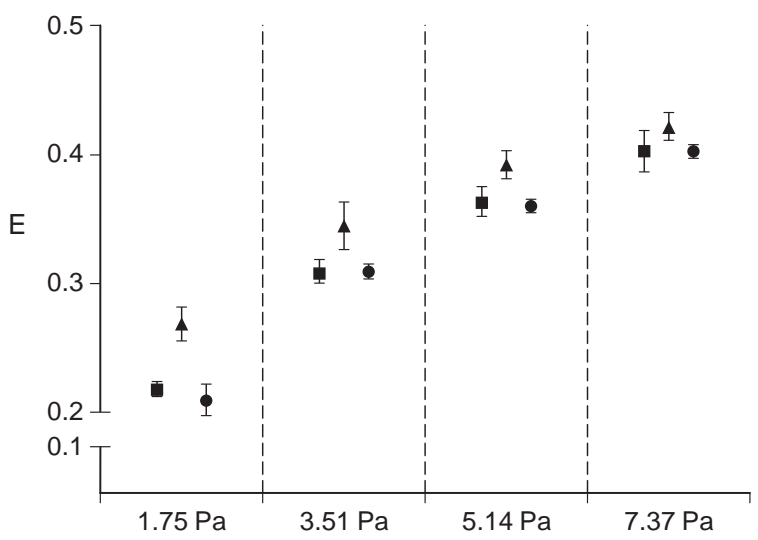

Fig. 7. Inhibition of $\mathrm{Na}^{+}-\mathrm{K}^{+}$-ATPase abolishes the effect of $\mathrm{C}$ peptide. Erythrocytes of Type I diabetic patients $(n=5)$ were incubated with $6.6 \mathrm{nmol} / \mathrm{l} \mathrm{C}$-peptide for $4 \mathrm{~h}$. Erythrocyte deformability was again found to be ameliorated by $+6.6 \mathrm{nmol} / \mathrm{l}$ C-peptide treatment $(\boldsymbol{\Delta})$ compared with untreated diabetic controls $(\square)$, as shown at representative physiological shear rates of $1.75 \mathrm{~Pa}(p<0.0001), 3.51 \mathrm{~Pa}(p=0.01), 5.14 \mathrm{~Pa}$ $(p<0.001)$ and $7.37 \mathrm{~Pa}(p<0.05)$. Inhibition of $\mathrm{Na}^{+}-\mathrm{K}^{+}-\mathrm{AT}-$ Pase by ouabain (O) completely suppressed the beneficial effect of C-peptide on erythrocyte deformability (statistically not different from untreated erythrocytes)

concerning the underlying mechanisms. Blood flow in larger vessels is determined by the vessel diameter, the viscosity (erythrocyte deformability and whole blood viscosity) and vessel length according to the law of Hagen-Pouiseuille. In smaller vessels of the microvasculature, especially if the diameter of the vessel is smaller than the diameter of the erythrocytes, as found in capillaries, blood flow is predominantly determined by the viscosity and deformability of the erythrocytes. Thus, reduced deformability leads to reduced flow in microcirculation if the capil- lary diameter and blood pressure remain constant [35]. A well-known example emphasising the impact of deformability of erythrocytes in microcirculation is sickle cell disease, in which sequestration of erythrocytes takes place in capillaries, leading to severe disturbances in the microvasculature [36].

The rheologic properties of erythrocytes in diabetes have been the subject of numerous studies. These studies showed that several factors, such as decreased erythrocyte deformability, increased erythrocyte aggregation and increased membrane microviscosity, contribute to alterations of the rheological properties [15-22]. They have been related to the modification of proteins and lipids by advanced glycation end products, to the generation of free oxygen radicals and to changes in ion homeostasis by hyperglycaemia. Nevertheless, some authors could not find any differences in erythrocyte deformability in diabetic patients. The lack of methodological comparability could be the reason for this phenomenon [15, 37]. For example, measurement of the passing velocity of erythrocytes through micropores is a common technique [19]. Many problems, such as the presence of doublet and triplet pores, aggregation of erythrocytes and occlusion of micropores, contribute to an intraassay variability of up to $10 \%$ with a subsequent loss of sensitivity of the method.

Concerning the possible mechanism of reduced erythrocyte deformability, note that $\mathrm{Na}^{+}-\mathrm{K}^{+}$-ATPase activity has been shown to be attenuated in several cell types including erythrocytes in diabetic patients $[16,38,39]$ and that it could be restored not only by insulin but also by C-peptide [38]. This is of clinical importance because some Type I diabetic patients maintain a measurable level of beta cell activity for many years and the frequency of microvascular lesions in these patients is negatively correlated to residual islet cell function $[40,41]$. These finding have generally been interpreted as indicating that remaining betacell secretion of (endogenous) insulin exerts a beneficial effect on glycaemic control. It is not, however, apparent why endogenous insulin should be more protective than exogenous insulin. These arguments raised the hypothesis that rather than facilitating the steric formation of the proinsulin molecule, proinsulin C-peptide may have a more physiological impact; C-peptide has been shown to ameliorate renal and nerval variables in diabetic patients [10-12]. Recently, we showed that replacement of proinsulin C-peptide in Type I diabetic patients leads to a redistribution of skin microvascular blood flow to levels similar to those in healthy subjects by increasing the nutritive capillary blood cell velocity relative to subpapillary arteriovenous shunt flow [13]. In addition, we found that C-peptide can activate endothelial nitric oxide synthase by increasing the intracellular influx of calcium ions [14]. These findings concerning the microcirculatory effects of C-peptide led to the suggestion 
that the peptide may also influence the rheologic properties of erythrocytes. In this study, we investigated the deformability of erythrocytes in Type I diabetic patients, i.e. C-peptide-deficient subjects, compared with healthy control subjects. Deformability was tested under physiological ( 0.3 to $10 \mathrm{~Pa}$ ) and supraphysiological ( > $10 \mathrm{~Pa}$ ) shear stress rates by laser diffractoscopy. The erythrocyte deformability was considerably lower in the diabetic group (Fig. 3), e.g. at a physiological shear rate of $7.1 \mathrm{~Pa}$ from $\mathrm{E}=0.4306 \pm 0.006$ to $\mathrm{E}=0.3794 \pm 0.023 \quad(p=0.002)$. In a further trial, erythrocytes from healthy control subjects and Type I diabetic patients were incubated with different concentrations of C-peptide similar to basal physiological $(0.6 \mathrm{nmol} / \mathrm{l})$, postprandial physiological $(6.6 \mathrm{nmol} / \mathrm{l})$ and supraphysiological $(66.6 \mathrm{nmol} / \mathrm{l})$ concentrations. Treatment with C-peptide restored the previously decreased deformability of diabetic erythrocytes compared with control erythrocytes of healthy volunteers, leaving a non-significant difference between the two groups. In contrast, proinsulin C-peptide had no additional effect on the deformability of control erythrocytes. This is sufficiently explained by the control patients naturally showing basal serum C-peptide concentrations, which, exerted maximum effects on deformability in the present study. In agreement with these findings, the effect of proinsulin C-peptide on skin microcirculation in non-diabetic control subjects was absent [13].

Furthermore, the different concentrations of Cpeptide exerted similar effects on erythrocyte deformability. This underlines that basal physiological concentrations of proinsulin C-peptide are sufficient to restore the deformability of diabetic erythrocytes. Finally, the beneficial effect of C-peptide was found to be constant over a period of $8 \mathrm{~h}$, which excludes tachyphylaxis or substantial degradation of the peptide in this short-term study.

To hypothesise the potential mechanism of effect of proinsulin C-peptide, previous studies of $\mathrm{Na}^{+}-\mathrm{K}^{+}$ATPase activity in renal tubular cells and erythrocytes of diabetic subjects are of considerable interest $[16,38,39]$. It has been found [38] that the attenuated activity of $\mathrm{Na}^{+}-\mathrm{K}^{+}$-ATPase activity in renal tubular segments of diabetic rats could be restored by proinsulin C-peptide. On the other hand, attenuation of $\mathrm{Na}^{+}-\mathrm{K}^{+}$-ATPase activity has been shown to correlate with decreased deformability in erythrocytes of Type I diabetic patients [16]. In a recent study [42] it was found that $\mathrm{Na}^{+}-\mathrm{K}^{+}$-ATPase activity is not only decreased in erythrocytes of Type I diabetic patients but in C-peptide-deficient Type II diabetic patients as well. Moreover, they found that the fasting C-peptide concentration in Type II diabetic patients was the only factor independently correlated with $\mathrm{Na}^{+}$$\mathrm{K}^{+}$-ATPase activity.

Impaired $\mathrm{Na}^{+}-\mathrm{K}^{+}$-ATPase activity may contribute to the decrease of erythrocyte deformability by in- creasing the intracellular sodium concentration with subsequent intracellular accumulation of free calcium ions due to competition in transmembranous exchange [43]. These abnormalities in calcium homeostasis are known to enhance spectrin dimer-dimer interaction and spectrin-protein 4.1-actin interaction $[44,45]$. The latter is promoted by adducin, a membrane-skeleton-associated protein with calmodulinbinding activity [46].

Thus, it can be speculated that this novel effect of C-peptide on erythrocyte deformability which has been described is mediated by $\mathrm{Na}^{+}-\mathrm{K}^{+}$-ATPase restoration. To characterise the impact of $\mathrm{Na}^{+}-\mathrm{K}^{+}$-ATPase on this C-peptide-related amelioration of cell deformability, erythrocytes of Type I diabetic patients in this study were pretreated with ouabain prior to C-peptide incubation and laser diffractoscopy. Interestingly, the beneficial effect of C-peptide was completely suppressed. These findings strengthen the hypothesis that the restoration of erythrocyte deformability by proinsulin C-peptide is mediated by an increase of $\mathrm{Na}^{+}-\mathrm{K}^{+}$-ATPase activity.

In conclusion, proinsulin C-peptide is most probably involved in the physiological regulation of microcirculation and rheology.

Acknowledgements. We would like to thank M. Löbig and $\mathrm{V}$. Nguyen for their excellent technical assistance.

\section{References}

1. Rubenstein AH, Clark JL, Melani F, Steiner DF (1969) Secretion of proinsulin C-peptide by pancreatic beta cells and its circulation in blood. Nature 224: 697-699

2. Steiner DF (1978) On the role of proinsulin C-peptide. Diabetes 27 [Suppl] 145-148

3. Steiner DF, Oyen PE (1967) The biosynthesis of insulin and a probable precursor of insulin by a human islet cell adenoma. Proc Natl Acad Sci USA 57: 473-480

4. Kitabchi AE (1970) The biological and immunological properties of pork and beef insulin, proinsulin, and connecting peptides. J Clin Invest 49: 979-987

5. Hoogwerf BJ, Bantle JP, Gaenslen HE (1986) Infusion of synthetic human C-peptide does not effect plasma glucose, serum insulin, or plasma glucagon in healthy subjects. Metabolism 35: 122-125

6. Wahren J, Johansson BL (1998) New aspects of C-peptide physiology. Horm Met Res 30:A2-A5

7. Cohen P, Barzilai N, Karnieli E (1995) Suppression of insulin secretion by C-peptide infusions in humans. Isr J Med Sci 31: 284-288

8. Johansson BL, Linde B, Wahren J (1992) Effects of C-peptide on blood flow, capillary diffusion capacity and glucose utilization in the exercising forearm of type 1 (insulin-dependent) diabetic patients. Diabetologia 35: 1151-1158

9. Zierath JR, Galuska D, Johansson BL, Wallberg-Henriksson H (1991) Effect of human C-peptide on glucose transport in in vitro incubated skeletal muscle. Diabetologia 34: 899-901

10. Johansson BL, Sjöberg S, Wahren J (1992) The influence of human $\mathrm{C}$-peptide on renal function and glucose utilisation 
in type 1 (insulin dependent) diabetic patients. Diabetologia 35: 121-128

11. Johansson BL, Kernell A, Sjöberg S, Wahren J (1993) Influence of combined C-peptide and insulin administration on renal function and metabolic control in diabetes type 1. J Clin Endocrinol Metab 77: 976-981

12. Johansson BL, Borg K, Fernqvist-Forbes E, Odergren T, Remahl S, Wahren J (1996) C-peptide improves autonomic nerve function in patients with type 1 diabetes. Diabetologia 39: 687-695

13. Forst T, Kunt T, Pohlmann Tet al. (1998) Biological activity of C-peptide on the skin microcirculation in patients with insulin-dependent diabetes mellitus. J Clin Invest 101: 2036-2041

14. Kunt T, Forst T, Lehmann R et al. (1998) Human C-peptide increases calcium influx into endothelial cells. Diabetes 47 [Suppl] A30

15. Bareford D, Jennings PE, Stone PCW, Baar S, Barnett AH, Stuart J (1986) Effects of hyperglycemia and sorbitol accumulation on erythrocyte deformability in diabetes mellitus. J Clin Pathol 39: 722-727

16. Finotti P, Palatini P (1986) Reduction of erythrocyte $\left(\mathrm{Na}^{+}-\right.$ $\mathrm{K}^{+}$)ATPase activity in type 1 (insulin-dependent) diabetic subjects and its activation by homologous plasma. Diabetologia 29: 623-628

17. Chimori K, Miyazaki S, Kosaka J, Sakanaka A, Yasuda K, Miura K (1986) Increased sodium influx into erythrocytes in diabetes mellitus and hypertension. Clin Exp Theory Practice A8(2):185-199

18. Cohen NS, Ekholm JE, Luthra ME, Hanahan W (1976) Biochemical characterization of density-separated human erythrocytes. Biochim Biophys Acta 419: 229-242

19. McMillan DE, Utterback NG, La Puma J (1978) Reduced erythrocyte deformability in diabetes. Diabetes 27: 895-901

20. Ernst E, Matrai A (1986) Altered red and white blood cell rheology in type II diabetes. Diabetes 35: 1412-1415

21. Baba Y, Kai M, Kamada T, Setoyama S, Otsuji S (1979) Higher levels of erythrocyte membrane microviscosity in diabetes. Diabetes 28: 1138-1140

22. Schmid-Schönbein H, Volger E (1976) Red-cell aggregation and red cell deformability in diabetes. Diabetes 25: 897-902

23. King GL, Brownlee M (1996) The cellular and molecular mechanisms of diabetic complications. Endocrinol Metab Clin North Am 25: 255-270

24. Bailey AJ, Robins SD, Tanner WA (1976) Reducible components in the proteins of human erythrocyte membrane. Biochim Biophys Acta 434: 51-57

25. Rabini RA, Petruzzi E, Staffoani R et al. (1997) Diabetes mellitus and subjects' aging: a study on the ATP content and the ATP-related enzyme activities in human erythrocytes. Eur J Clin Invest 27: 327-332

26. Persson SU, Wohlfahrt G, Larsson H, Gustafson A (1996) Correlations between fatty acid composition of the erythrocyte membrane and blood rheology data. Scand J Clin Lab Invest 56: 183-190

27. Flieger R, Grabe R (1997) Cell-elastometry: a new method to measure erythrocyte membrane elasticity. Biorheology 34: 223-234

28. Kohno M, Murakawa K, Yasunari K et al. (1997) Improvement of erythrocyte deformability by cholesterol-lowering therapy with pravastatin in hypercholesterolemic patients. Metabolism 46: 287-291
29. Baskurt OK, Gelmont D, Meiselmann HJ (1998) Red blood cell deformability in sepsis. Am J Respir Crit Care Med 157: 421-427

30. Tooke JE (1995) Microvascular function in human diabetes. Diabetes 44: 721-726

31. Corbin DOC, Young RJ, Morrison DC et al. (1987) Blood flow in the foot, polyneuropathy and foot ulceration in diabetes mellitus. Diabetologia 30: 468-473

32. Bennaroch EE, Low PA (1991) The acetylcholine-induced flare response in evaluation of small fibre dysfunction. Ann Neurol 29: 590-595

33. Ruggiero D, Lecomte M, Michaud E, Lagarde M, Wiernsberger N (1997) Involvement of cell-cell interactions in the pathogenesis of diabetic retinopathy. Diabetes Metab 23: $30-42$

34. Kunt T, Forst T, Harzer OJ et al. (1998) The influence of advanced glycation endproducts (AGE) on the expression of human endothelial adhesion molecules. Exp Clin Endocrinol Diabetes 106: 183-188

35. Chien S (1987) Red cell deformability and its relevance to blood flow. Ann Rev Physiol 49: 177-192

36. Sarrat P, Serise JM, Freyburger G, Lorient-Roudaut MF, Boisseau MR (1987) Hemorheologic study of different forms of vasomotor acrosyndromes. J Mal Vasc 12: 113-116

37. Schut NH, van Arkel EC, Hardeman MR, Bilo HJG, Michels RPJ, Vreeken J (1993) No decreased erythrocyte deformability in type 1 (insulin-dependent) diabetes, either by filtration or by ektacytometry. Acta Diabetol 30: 89-92

38. Ohtomo Y, Aperia A, Sahlgren B, Johansson BL, Wahren J (1995) C-peptide stimulates rat renal tubular $\mathrm{Na}^{+} \mathrm{K}^{+} \mathrm{AT}-$ Pase activity in synergism with neuropeptide Y. Diabetologia 39: 199-205

39. Ohtomo Y, Bergman T, Johansson BL, Jörnvall H, Wahren J (1998) Differential effects of proinsulin C-peptide fragments on $\mathrm{Na}^{+} \mathrm{K}^{+}$ATPase activity of renal tubule segments. Diabetologia 41: 287-291

40. Sjöberg S, Gunnarson R, Gjötterberg M, Persson A, Östman J (1987) Residual insulin production and prevalence of microvascular lesions and polyneuropathy in long-term type 1 (insulin-dependent) diabetes mellitus. Diabetologia 30: 208-213

41. Kernell A, Ludvigsson J, Finnström K (1990) Vitreous fluorophotometry in juvenile diabetics with and without retinopathy in relation to metabolic control: insulin antibodies and C-peptide levels. Acta Ophthalmol Scand 68: 415-420

42. Dufayet De La Tour D, Raccah D, Jannot MF, Coste T, Rougerie C, Vague P (1998) Erythrocyte Na/K ATPase activity and diabetes: relationship with $\mathrm{C}$-peptide level. Diabetologia 41: 1080-1084

43. Mazzanti L, Rabini RA, Faloia E, Fumelli P, Bertoli E, De Pirro R (1990) Altered cellular $\mathrm{Ca}^{2+}$ and $\mathrm{Na}^{+}$transport in diabetes mellitus. Diabetes 39: 850-854

44. Takakuwa Y, Mohandas N (1988) Modulation of erythrocyte membrane material properties by $\mathrm{Ca}^{2+}$ and calmodulin. J Clin Invest 82: 394-400

45. Schischmanoff PO, Winardi R, Discher DE, Parra MK, Bicknese SE, Witkowska HE, Conboy JG, Mohandas N (1995) Defining of the minimal domain of protein 4.1 involved in spectrin-actin binding. J Biol Chem 270: 21243-50

46. Gardner K, Bennett V (1986) A new erythrocyte membrane-associated protein with calmodulin binding activity: identification and purification. J Biol Chem 261: 1339-1348 